\title{
Coronavirus-SARS-CoV-2: Biology and Problems in rRT-PCR Detection
}

Maelita Ramdani Moeis 10
Anis Puji Rahayu 2*
Nisa Ihsani 10
Wulan Pertiwi 10
1Department of Biotechnology,
Universitas Muhammadiyah Bandung,
Bandung, West Java, Indonesia
2Department of Pharmacy, Universitas
Muhammadiyah Bandung, Bandung,
West Java, Indonesia
*email: anis.puji.rahayu@hotmail.com
Keywords:
COVID-19
Detection
False results
rRT-PCR
SARS-CoV-2

\begin{abstract}
Coronavirus disease 2019 (COVID-19) first appeared in China in December 2019 and was declared a pandemic by the World Health Organization. COVID-19 is caused by Severe Acute Respiratory Syndrome Corona Virus 2 (SARS-CoV-2), a new virus previously unknown to humans. Here we look at what is known about this virus, the main method for detecting the presence of this virus in a person who is used as a golden standard, and the problems that could arise in this detection method. Understanding the biology of the virus and the strengths and weaknesses of the detection method are important for patient management and for overcoming the pandemic.
\end{abstract}

Received: May 31st, 2020

Accepted: June $16^{\text {th }}, 2020$

Published: June 22nd, 2020

(C) 2020 Maelita Ramdani Moeis, Anis Puji Rahayu, Nisa Ihsani, Wulan Pertiwi. Published by Institute for Research and Community Services Universitas Muhammadiyah Palangkaraya. This is an Open Access article under the CC-BY-SA License (http://creativecommons.org/licenses/by-sa/4.0/). DOI: https:// doi.org/10.33084/ bjop.v3iSpecial-1.1429

\section{INTRODUCTION}

In December 2019, a severe respiratory disease appeared in China, which is now named coronavirus disease 2019 (COVID-19) (World Health Organization, 2020a). The World Health Organization has declared the COVID-19 outbreak a pandemic. This disease has spread to 215 countries, infecting more than six million people and causing more than 370 thousand deaths as of May 31 3 st, $^{\text {st }}$ 2020 (Worldometer, 2020). COVID-19 is a disease caused by Severe Acute Respiratory Syndrome Corona Virus 2 (SARS-CoV-2) infection with symptoms of cough, fever, fatigue, headache, and shortness of breath (Guan et al., 2020; Wang et al., 2020).

The diagnosis of COVID -19 is made through observing the clinical manifestations that arise and the diagnostic examination of SARS-CoV-2. The SARS-CoV-2 diagnostic tests are carried out through Reverse Transcription polymerase chain reaction (RT-PCR) testing as a method to confirm the diagnosis of cases of COVID-19 according to WHO guidelines (World Health Organization, 2020b). In this paper, we discuss the biology of SARS-CoV-2 and the principles of RT-PCR as the basis to understand the method of detection of SARS$\mathrm{CoV}-2$ and problems that may occur using this detection method.

\section{SARS-CoV-2 BIOLOGY}

The SARS-Cov-2, an agent causing a disease called COVID-19 is a new species of coronaviruses. The disease was first reported in Wuhan, China in 2019 (World Health Organization, 2020a). Coronavirus belongs to the order of Nidovirales, identified by its envelope 
characteristics and positive-sense RNA as genetic material. The length of the coronavirus genome is about 26,4-31,7 kb. Coronaviridae and Roniviridae family are the largest RNA virus among other viruses (King et al., 2011). The SARS-CoV-2 genome is $29.9 \mathrm{~kb}$ (Forster et al., 2020).

As a member of Nidovirales, coronavirus is classified into the family of Coronaviridae which usually has three or four envelope proteins. Viruses that belong to Coronaviridae family have the most abundant membrane protein $(\mathrm{M})$ among other proteins, i.e. spike glycoprotein $(S)$, nucleocapsid protein $(\mathrm{N})$, an envelope protein $(\mathrm{E})$, dan hemagglutinin-esterase protein $(\mathrm{HE})$ as visualized in Figure 1 by King et al. (2011).

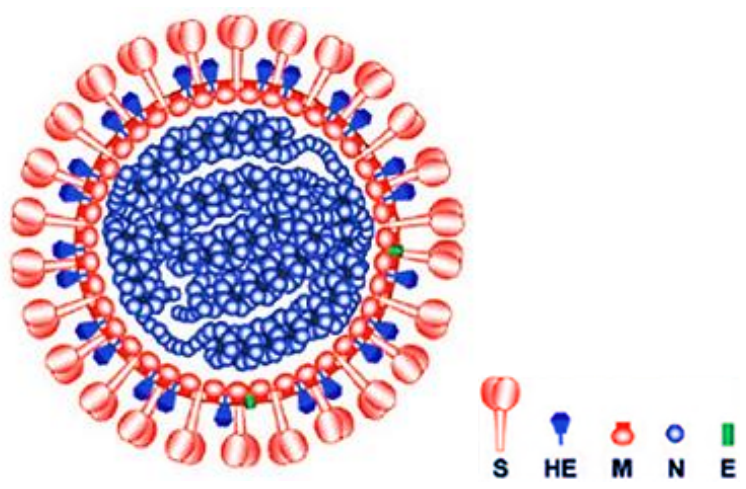

Figure 1. Envelope structure of coronavirus. The outer layer of coronavirus consists of S, HE (only found in Betacoronavirus cluster), M, N, and E protein (King et al., 2011)

Coronavirus has a few E proteins on the outer layer of its envelope. It is a pentameric integral membrane protein that facilitates the movement of molecules passing through the ion channel and/or viroporin. Even though there is only a small number of this protein, it was identified as an essential element of virion morphogenesis and a virulent factor of Severe Acute Respiratory Syndrome Virus (SARS)-CoV (King et al., 2011). Wan et al. (2020) reported that SARS-CoV-2 and b bat SARS-like coronavirus were in the same $b$ genus. Both were also originated from the same ancestral line. Human SARS-CoV and batSARS-CoV can infect a target cell through angiotensin-converting enzyme 2 (ACE2) receptor. Alignment of Receptor-Binding Domain (RBD) of SARS-CoV and SARS-CoV-2 showed that SARS-CoV2 RBD had a mutation on 105 residues. It was predicted that the mutation can enhance the affinity of SARS-CoV2 RBD to the ACE2 receptor (Wan et al., 2020).

Spike glycoprotein $(S)$ is one of the targets of $\mathrm{T}$ cell response in the immune system. It acts as an inducer in the neutralization of virus infectivity by antibodies (King et al., 2011). TheS protein also promotes the binding of the virus envelope to the ACE2 receptor and the entry of the virus into the cell target (Wan et al., 2020).

Angiotensin-converting enzyme 2 genes are expressed in several human cells including endothelial cells of small and large arteries and veins, smooth muscle cells, enterocytes of the small intestine (duodenum, jejunum, and ileum), alveolar epithelial cells, basal cell layer of the epidermis hair follicle, cardiac myofibroblast and fat cell membrane in several organs, smooth muscle cells surrounding the sebaceous glands in the skin, endothelial and smooth muscle cell of the brain, parietal epithelial cell of the kidney, and proximal tubular cell of the kidney. Epithelial cells of lungs and small intestine contain an abundant amount of ACE2 protein. However, ACE2 protein is not identified in the upper respiratory tract, such as an oral cavity, nasal mucosa, and nasopharynx. It is also not identified in enterocytes of the stomach and colon, endothelial lining of the sinusoids liver, spleen, lymph nodes, thymus, immune cells (B cell, T lymphocyte, and macrophage), bone marrow, and kidney (Hamming et al., 2004). Despite ACE2 proteins are scattered all over endothelial and smooth muscle cells, not every organ is infected by a coronavirus. SARS-CoV2 may need a co-receptor as in found in HIV. The HIV requires surface receptor $\mathrm{CD} 4$ and chemokine coreceptor for infecting and entering the cell target (Zhang et al., 1996). 


\section{POLYMERASE CHAIN REACTION}

Polymerase Chain Reaction (PCR) is a DNA amplification technique that was invented by Karl Mullis in 1984 (Mullis, 1987). This technology is commonly used for pathogen identification, forensic analysis (Schaad \& Frederick, 2002), gene identification, and genetic engineering (Garibyan \& Avashia, 2013). The principle of the PCR process is the alteration of temperature using DNA polymerase used in DNA replication in the living cells. The temperature is altered to facilitate denaturation (separating DNA double-stranded), annealing (primer attachment to DNA template), and elongation (DNA amplification) process. There are several main components required for amplification in the PCR process: DNA sample, DNA polymerase enzyme, primer, and buffer. The reaction is catalyzed by DNA polymerase using a DNA sample as a template (Joshi \& Deshpande, 2011).

Primers are short pieces of single-stranded DNA that can be designed for restricting the segment of DNA target (Schaad \& Frederick, 2002). In the process of amplification, the sample is used in a small amount. Therefore, PCR becomes a sensitive technique for DNA identification (Garibyan \& Avashia, 2013).

Molecular biologists have developed variations of the original PCR process such as Reverse Transcriptase PCR (RT-PCR), Real-time PCR, and Quantitative PCR (qPCR). The RT-PCR is a PCR technique that uses RNA as the original template. It uses reverse transcriptase for DNA synthesis from the RNA template followed by PCR. Realtime PCR can observe the amplification product in realtime, during the PCR process by using a fluorescent label that binds to the final PCR product (Higuchi et al., 1993; Deepak et al., 2007). The qPCR can be used to quantify nucleic acids at a specific time. For gene expression studies, RT-PCR, real-time PCR, and qPCR are combined into one process called RT- qPCR or rRT-PCR. This process includes DNA synthesis from an RNA template using reverse transcriptase, followed by PCR, detection, and quantification. This method is used for the diagnosis of the Coronavirus disease or COVID-19 since SARS$\mathrm{CoV}-2$ is an RNA virus. This test is accurate and sensitive enough for detecting SARS-CoV-2 in samples (Long et al., 2020; Tahamtan \& Ardebili, 2020).

\section{RT-PCR KITS}

Real-time PCR is the most sensitive method to detect the presence of the virus that causes COVID-19. Real-time PCR can detect viruses with a detection limit (analytical sensitivity) of 1000 copies $/ \mathrm{mL}$, this analytical sensitivity depends on sample volume, elution volume, and RNA extraction methods, and other factors (Tahamtan \& Ardebili, 2020). Many RT-PCR kits can be used as diagnostic tools for COVID-19. van Kasteren et al. (2020) compared the performance of seven RT-PCR kits. The kits that were assessed are shown in Table I.

Table I. RT-PCR kits for COVID-19 diagnosis (van Kasteren et al., 2020)

\begin{tabular}{|c|c|c|c|c|}
\hline 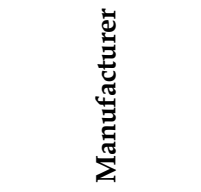 & 苞 & 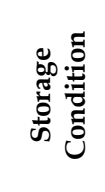 & 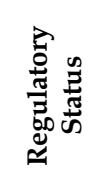 & 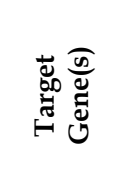 \\
\hline $\begin{array}{l}\text { Altona } \\
\text { Diagnostics }\end{array}$ & Germany & $-20^{\circ} \mathrm{C}^{\mathrm{c}}$ & $\mathrm{RUO}^{\mathrm{a}}$ & $E^{b}, S$ \\
\hline BGI & China & $-20^{\circ} \mathrm{C}$ & $\begin{array}{l}\text { CE- } \\
\text { IVD }\end{array}$ & ORF1ab \\
\hline $\begin{array}{l}\text { CerTest } \\
\text { Biotec }\end{array}$ & Spain & $\begin{array}{l}\text { Room } \\
\text { Temp. }\end{array}$ & $\begin{array}{l}\text { CE- } \\
\text { IVD }\end{array}$ & $\begin{array}{l}\text { ORF1ab, } \\
\text { N }\end{array}$ \\
\hline KH Medical & Korea & $-20^{\circ} \mathrm{C}$ & $\begin{array}{l}\text { CE- } \\
\text { IVD }\end{array}$ & $\operatorname{RdRp}, \mathrm{S}$ \\
\hline PrimerDesign & England & $-20^{\circ} \mathrm{C}$ & $\begin{array}{l}\text { CE- } \\
\text { IVD }\end{array}$ & $\mathrm{RdRp}$ \\
\hline $\begin{array}{l}\text { R-Biopharm } \\
\text { AG }\end{array}$ & Germany & $-20^{\circ} \mathrm{C}$ & $\mathrm{RUO}^{\mathrm{d}}$ & $\mathrm{E}$ \\
\hline Seegene & Korea & $-20^{\circ} \mathrm{C}$ & $\begin{array}{l}\text { CE- } \\
\text { IVD }\end{array}$ & $\mathrm{N}, \mathrm{E}^{\mathrm{b}}$ \\
\hline $\begin{array}{l}\text { E: Envelope protei } \\
\text { CE-IVD: European } \\
\text { RdRp: RNA deper } \\
\text { N: Nucleocapsid p } \\
\text { ORFlab: Open Rec } \\
\text { RUO: Research Us } \\
\text { S: Spike protein of } \\
\text { aAccording to the } \\
\text { website states CE-I }\end{array}$ & $\begin{array}{l}\text { of SARSCov } \\
\text { onformity la } \\
\text { lent RNA po } \\
\text { tein of SARS } \\
\text { ling Frame 1 } \\
\text { Only } \\
\text { ARSCov-2 } \\
\text { nanufacturer }\end{array}$ & $\begin{array}{l}\text { l-in Vitro } \\
\text { merase of } \\
\text { and }-2\end{array}$ & $\begin{array}{l}\text { gnostics } \\
\text { RSCov-2 } \\
\text { SCov-2 }\end{array}$ & the FindDx \\
\hline
\end{tabular}


bThese E-gene assays are specific for bat (-related) beta coronaviruses. They detect both SARS-CoV-1 and -2 .

Shipment is performed at room temperature.

dAccording to the manufacturer, CE-IVD certification will be applied shortly.

All RT-PCR kits performed splendid results with PCR efficiency $\geq 96 \%$. All RT-PCR were able to identify positively 10 out of 13 selected clinical samples with various concentrations, with the highest concentrations of SARS-CoV-2 RNA with Ctless than 34.5 in an in-house E-gene PCR. None of the assays showed cross-reactivity with a confirmed non-coronavirus respiratory viral infection. When performing diagnostics in a low viral loads condition such as in mild or no symptoms or patients during the later stage of infection or health-care workers (Zou et al., 2020), RT-PCR kits from R-Biopharm AG, BGI, KH Medical, and Seegene had the best performance in identification of the clinical samples. All the RT-PCR kits assessed in the study may be used for routine diagnostics of COVID-19 in patients by experienced molecular diagnostic laboratories.

\section{RT-PCR TEST SAMPLES}

In general, most patients only develop mild $(40 \%)$ or moderate $(40 \%)$ disease, $15 \%$ develop in the severe condition that requires oxygen support, and $5 \%$ have a critical disease with complications such as respiratory failure, acute respiratory distress syndrome (ARDS), sepsis and septic shock, thromboembolism, and/or multiorgan failure, including acute kidney injury and cardiac injury (World Health Organization, 2020c). RTPCR test samples for initial diagnosis come from the upper respiratory tract (URT) in the form of nasopharyngeal (NP) and oropharyngeal (OP) swabs, nasopharyngeal wash/nasopharyngeal aspirate, nasal swab, or nasal mid-turbinate swab. If the URT specimen shows a negative result, then the specimen is taken from the lower respiratory tract (LRT) consisting of sputum, aspirate, or lavage (Center for Disease Control and Prevention, 2020a; World Health Organization, 2020b). In other considerations, stools can be used as specimens for RT-PCR samples (World Health Organization, 2020b). Some patients show negative swabs, but viral RNA can be detected in the stool (Hindson, 2020; Lo et al., 2020; Wölfel et al., 2020). The specimen is collected as soon as possible in the initial onset (Center for Disease Control and Prevention, 2020b). Research showed that the viral loads in throat swab and sputum peaked in 5-6 days after symptom onset (Pan et al., 2020). Another research indicated that viral load was higher in the nose (NP and OP swabs) than in the throat (Zou et al., 2020).

The use of NP swabs as a specimen is preferred over OP swabs due to higher detection rates. This is consistent with research that demonstrates early viral development in the nasal/NP (Wang et al., 2020). Sampling techniques through swabs must be performed at the right anatomy and time so that negative-false can be avoided. Besides, only synthetic fiber swabs with plastic or wire shafts are used (Center for Disease Control and Prevention, 2020b). In NP swabs, mini tip swabs are inserted into the nose parallel to the palate until they reach the tip, namely the nasopharynx. Gently rub and roll the swab and wait a few seconds to absorb the secretion. Then slowly remove the swab while rotating it. The technique for collecting specimens in the form of an NP swab is illustrated in Figure 2. The OP swab is done by inserting the swab into the posterior pharynx and tonsillary areas (Center for Disease Control and Prevention, 2020b; World Health Organization, 2020b). Each swab is put into a sterile container containing 2-3 mL viral transport medium (VTM), Amies transport medium, or sterile saline. The specimens for LRT are placed in dry and sterile containers (Center for Disease Control and Prevention, 2020b). 


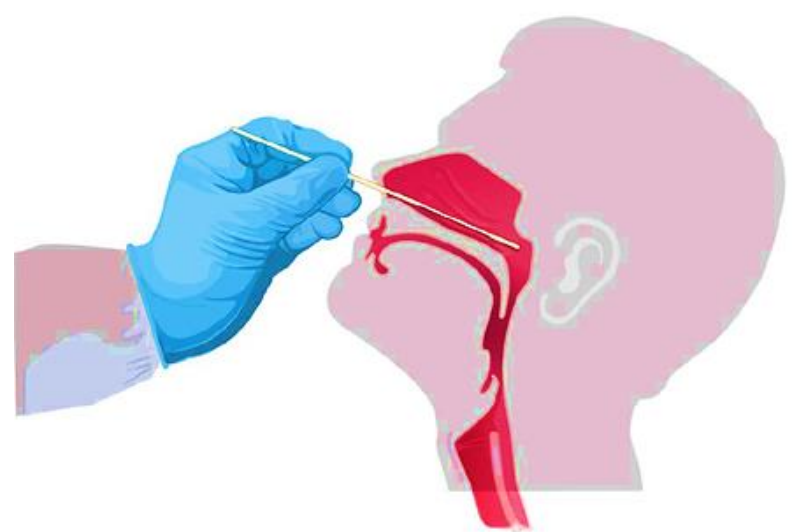

Figure 2. Nasopharyngeal Swab (Center for Disease Control and Prevention, 2020b)

Collected specimens are stored at $2-8^{\circ} \mathrm{C}$ for up to 72 hours. If a delay in testing or shipping is expected, store specimens at $-70^{\circ} \mathrm{C}$ or below (Center for Disease Control and Prevention, 2020b). Complete information about specimen collection and storage is in Table II.

Table II. Specimen collection and storage (Center for Disease Control and Prevention, 2020b; World Health Organization, 2020a)

\begin{tabular}{|c|c|c|c|}
\hline Specimen type & $\begin{array}{l}\text { Collection } \\
\text { materials }\end{array}$ & $\begin{array}{c}\text { Storage } \\
\text { temperature } \\
\text { until testing } \\
\text { in-country } \\
\text { laboratory }\end{array}$ & $\begin{array}{c}\text { The } \\
\text { recommended } \\
\text { temperature } \\
\text { for shipment } \\
\text { according to } \\
\text { expected } \\
\text { shipment time }\end{array}$ \\
\hline $\begin{array}{c}\text { Nasopharyngeal } \\
\text { and } \\
\text { oropharyngeal } \\
\text { swab }\end{array}$ & $\begin{array}{l}\text { Dacron or } \\
\text { polyester } \\
\text { flocked } \\
\text { swabs }\end{array}$ & $2-8^{\circ} \mathrm{C}$ & $\begin{array}{c}2-8^{\circ} \mathrm{C} \text { if } \leq 12 \\
\text { days } \\
-70^{\circ} \mathrm{C} \text { (dry ice) } \\
\text { if }>12 \text { days }\end{array}$ \\
\hline $\begin{array}{c}\text { Bronchoalveolar } \\
\text { lavage }\end{array}$ & $\begin{array}{c}\text { Sterile } \\
\text { container }^{*}\end{array}$ & $2-8^{\circ} \mathrm{C}$ & $\begin{array}{c}2-8^{\circ} \mathrm{C} \text { if } \leq 2 \text { days } \\
-70^{\circ} \mathrm{C} \text { (dry ice) } \\
\text { if }>2 \text { days }\end{array}$ \\
\hline $\begin{array}{l}\text { (Endo)tracheal } \\
\text { aspirate, } \\
\text { nasopharyngeal } \\
\text { or nasal } \\
\text { wash/aspirate }\end{array}$ & $\begin{array}{c}\text { Sterile } \\
\text { container }\end{array}$ & $2-8^{\circ} \mathrm{C}$ & $\begin{array}{c}2-8^{\circ} \mathrm{C} \text { if } \leq 2 \text { days } \\
\left.-70^{\circ} \mathrm{C} \text { (dry ice }\right) \\
\text { if }>2 \text { days }\end{array}$ \\
\hline Sputum & $\begin{array}{c}\text { Sterile } \\
\text { container }\end{array}$ & $2-8^{\circ} \mathrm{C}$ & $\begin{array}{c}2-8^{\circ} \mathrm{C} \text { if } \leq 2 \text { days } \\
-70^{\circ} \mathrm{C} \text { (dry ice) } \\
\text { if }>2 \text { days }\end{array}$ \\
\hline Stool & $\begin{array}{c}\text { Stool } \\
\text { container }\end{array}$ & $2-8^{\circ} \mathrm{C}$ & $\begin{array}{c}2-8^{\circ} \mathrm{C} \text { if } \leq 5 \text { days } \\
-70^{\circ} \mathrm{C} \text { (dry ice) } \\
\text { if }>5 \text { days }\end{array}$ \\
\hline
\end{tabular}

"For transport of samples for viral detection, use viral transport medium (VTM) containing antifungal and antibiotic supplements. Avoid repeated freezing and thawing of specimens. If VTM is not available sterile saline may be used instead (in which case, duration of sample storage at $2-8^{\circ} \mathrm{C}$ may be different from what is indicated above).

Low viral load (World Health Organization, 2020b) is one of the things that can negatively impact the results of the
RT-PCR analysis. It is recommended that NP be collected twice from both sides of the nostrils or that OP and NP be combined in one VTM to maximize test sensitivity and limit the use of test resources (Center for Disease Control and Prevention, 2020b). The second factor is that the specimen was collected late or very early in the infection. Hence, it is very important to take specimens at the right time. The third is that the specimen was not properly handled and shipped. Another factor is the technical reasons inherent in the test, e.g. virus mutation or inhibition of PCR (World Health Organization, 2020b).

\section{STEPS IN INVESTIGATION OF COVID-19 SPECIMEN SAMPLES}

In Indonesia, The Ministry of Health has issued a direct procedure for handling the COVID-19 sample at the National Board of Health Research and Development. Specimen investigations have followed WHO standards and were carried out at the Biosafety Level 2 (BSL-2) Laboratorium. The investigation procedure is divided into three stages, consisting of acceptance, examination, and reporting. At the acceptance stage, specimens are taken from patients at the referral hospital and then sent to the National Board of Health Research and Development. To ensure further accuracy, not only one, but three specimens should be obtained from one patient. A swab sample from a COVID-19 patient is taken by a sampling officer with a Personal Protective Equipment (PPE) to be mixed with the VTM (Ministry of Health of the Republic of Indonesia, 2020a).

The VTM can be used to collect specimens from the throat and nasal swabs from human patients. This solution can be prepared locally based on the WHO recommendation. The VTM contains infusion broth, bovine albumin fraction $\mathrm{V}$, gentamicin sulfate, amphotericin B, and sterilized distilled water. Commercial VTM is also available such as COPAN 
Universal Transport Medium and Eagle Minimum Essential Medium (E-MEM) (World Health Organization, 2006).

Continuing to the examination stage, at this stage, the specimens received by the National Board of Health Research and Development are extracted for their RNA (Ribonucleic Acid) or viral genetic material. After the RNA is obtained, it is then used as a template for Reverse Transcriptase-Quantitative Polymerase Chain Reaction (RT-qPCR) to detect the presence of specific SARS CoV2 genes. COVID-19 diagnoses of patients are based on the RT-PCR test results (Ministry of Health of the Republic of Indonesia, 2020b).

In the RT-PCR process, there are negative and positive controls. In the negative control, the amplification of viral genes must not be found while in the positive control there must be an amplification of viral genes that are marked by curves. If the RT-PCR negative control is found to be positive, then the PCR process must be repeated (Bustin \& Nolan, 2004). The final stage is the reporting, there was indeed a special channel that needed to be done first to report or confirm the results. After interpretation of the results by RT-PCR experts, these results were sent to doctors who will carry out the next stage of verification and validation to report to the hospital and the health service (Espy et al., 2006).

\section{FALSE POSITIVE RESULTS IN THE RT- PCR TEST}

The false-positive result of the RT-PCR test means that the test is positive even if no virus is present in the sample tested. False-positive results of the RT PCR diagnostic tests are very unlikely. Positive results depend on the sequences of the primers and probes used, and possible cross-reactions with non-target sequences have usually already been ruled out during the design phase (Bustin \& Nolan, 2020).
For example, the SARS-CoV-2 rRT-PCR Diagnostic Panel primer and probe sequences were tested for homology with human genome sequences, other coronaviruses, and human microflora to prevent potential false-positive results (Center for Disease Control and Prevention, 2020a). No homology was found with the human genome and microflora sequences, but one of the primers or probes had homology with SARS-CoV and Bat SARS-like coronavirus genome. Since homologies with these coronavirus genomes were not present for the whole set of primers and the RT-PCR reaction probe, a false positive outcome would be unlikely (Corman et al., 2020). For a false-positive result to happen, the sample could have been contaminated with the virus (Tahamtan \& Ardebili, 2020). Contamination from equipment and reagent could be a source of false-positive results. Usually, this type of potential false positive would be detected by the use of negative control reactions. If the negative control reaction was positive, the test result would not have been valid and the test had to be repeated. This occurred in a test facility in Yala, Southern Thailand, where the negative controls of 40 specimens showed positive results. When the problematic specimens were sent to two other laboratories for analysis, the results were consistently negative. Machine error was suspected to be the cause of false-positive results (Thai Public Broadcasting Service World, 2020).

\section{FALSE NEGATIVE RESULTS IN THE RT- PCR TEST}

False-negative results from RT-PCR are much more common compared to false-positive results and have more serious consequences in the epidemiological management of the disease (Kalifarhood et al., 2020). Every RT PCR kits have a limit of detection, ranging from 200-1000 copies/mL, and this is the limit of detection 
under controlled laboratory conditions. Under real-life conditions, the limit of detection could become higher. Therefore, a low viral load could cause false-negative results. Mistakes during specimen collection, storage, and transportation could result in false-negative results (Jagodzinski et al., 2020).

Variations in the target sequence could cause falsenegative results. The SARS-CoV-2 has evolved into three central variants (Forster et al., 2020). Even though the design of primers and probes has taken into account variations in the SARS-CoV-2 genome sequences, new mutations could occur in the target sites.

The viral load would fluctuate during disease progression. From 72 nasal swabs and 72 throat swabs obtained from 18 patients in Zhuhai, Guangdong, China, the $\mathrm{Ct}$ value from 0 to 21 days after symptom onset fluctuated. A Ct value of 40 was considered to be negative and several patients $\mathrm{Ct}$ values decreased (positive results) after a previous $\mathrm{Ct}$ value of 40 (negative results), and some patients had inconsistent results (one positive and one negative) from nasal and throat swabs taken on the same day (Zou et al., 2020). Negative test results that later became positive were also observed in other longitudinal studies. According to Kucirka et al. (2020), from samples collected from the upper respiratory tracts, no virus could be detected with RT-PCR on the day of infection. On the day of symptom onset, the median false-negative rate was $38 \%$, and the lowest falsenegative rate of $20 \%$ was obtained from samples collected three days after symptom onset. Then the falsenegative rate would increase again, reaching $66 \%$ at 16 days after symptoms onset.

\section{CONCLUSION}

COVID-19 is caused by SARS-CoV-2, an enveloped RNA virus with a large genome $(29.9 \mathrm{~kb})$ closely related to human SARS-CoV and bat SARS-CoV. The $S$ protein on the surface of SARS-CoV-2 binds to the ACE2 receptor of the host and promotes entry of the virus into the cell target. ACE2 receptors are present in cells of the arteries, veins, smooth muscles, small intestine, alveoli of the lungs, hair follicles, cardiac myofibroblasts, skin, brain, and kidney, thus SARS-CoV-2 could potentially infect these tissues. The gold standard for detection or SARS$\mathrm{CoV}-2$ is by rRT-PCR and kits for SARS-CoV-2 detection are available commercially. Proper sampling site, sampling method, the timing of sampling, treatment, and handling of specimens during shipping and storage are all important in obtaining correct test results. Ongoing research is needed to select a better sampling site, timing, and treatment of samples to minimize false results which have serious consequences for the management of the disease.

\section{ACKNOWLEDGMENT}

We thank the Universitas Muhammadiyah Bandung for providing support for the completion of this article.

\section{REFERENCES}

Bustin, S.A. \& Nolan, T. (2020). RT-qPCR Testing of SARS-CoV-2: A Primer. International Journal of Molecular Sciences, 21(8), 3004. doi:10.3390/ijms21083004

Bustin, S.A. \& Nolan, T. (2004). Pitfalls of Quantitative Real-Time Reverse-Transcription Polymerase Chain Reaction. Journal of Biomolecular Techniques, 15(3), 155-166.

Center for Disease Control and Prevention. (2020a). CDC 2019-Novel Coronavirus (2019- $n$ CoV) Real-Time RT-PCR Diagnostic Panel. https://www.fda.gov/media/134922/down load

Center for Disease Control and Prevention. (2020b). Interim Guidelines for Collecting, Handling, and Testing Clinical Specimens for COVID-19. https://www.cdc.gov/coronavirus/2019ncov/lab/guidelines-clinical-specimens.html 
Corman, V.M., Landt, O., Kaiser, M., Molenkamp, R., Meijer, A., Chu, D.K.W., Bleicker, T., Brunink, S., Schneider, J., Schmidt, M.L., Mulders, D.G.J.C., Haagmans, B.L., van der Veer, B., van den Brink, S., Wijsman, L., Goderski, G., Romette, J.L., Ellis, J., Zambon, M., Peiris, Goossens, H., Reusken, C., Koopmans, M.P.G., \& Drosten, C. (2020). Detection of 2019 novel coronavirus (2019-nCoV) by real-time RTPCR. Eurosurveillance, 25(14), 20200409c. doi:10.2807/1560-

7917.ES.2020.25.14.20200409c

Deepak, S.A., Kottapalli, K.R., Rakwal, R., Oros, G., Rangappa, K.S., Iwahashi, H., Masuo, Y., \& Agrawal, G.K. (2007). Real-Time PCR: Revolutionizing Detection and Expression Analysis of Genes. Current Genomics, 8(4), 234251. doi:10.2174/138920207781386960

Espy, M.J., Uhl, J.R., Sloan, L.M., Buckwalter, S.P., Jones, M.F., Vetter, E.A., Yao. J.D.C., Wengenack, N.L., Rosenblatt, J.E., Cockerill, F.R., \& Smith, T.F. (2006). Real-Time PCR in Clinical Microbiology: Applications for Routine Laboratory Testing. Clinical Microbiology Reviews, 19(1), 165-256. doi:10.1128/CMR.19.1.165-256.2006

Forster, P., Forster, L., Renfrew, C., \& Forster, M. (2020). Phylogenetic Network Analysis of SARSCoV-2 Genomes. Proceedings of the National Academy of Science of the United States of America, 117(17), 9241-9243. doi:10.1073/pnas.2004999117

Garibyan, L., \& Avashia, N. (2013). Research Techniques Made Simple: Polymerase Chain Reaction (PCR). Journal of Investigative Dermatology, 133(3), e6. doi:10.1038/jid.2013.1

Guan, W., Ni, Z., Hu, Y., Liang, W., Ou, C., He, J., Liu, L., Shan, H., Lei, C., Hui, D. S. C., Du, B., Li, L., Zeng, G., Yuen, K. Y., Chen, R., Tang, C., Wang, T., Chen, P., Xiang, J., \& Zhong, N. (2020). Clinical Characteristics of Coronavirus Disease 2019 in China. The New England Journal of Medicine, 382(18), 1708-1720. doi:10.1056/NEJMoa2002032

Hamming, I., Timens, W., Bulthuis, M.L.C., Lely, A.T., Navis, G.J., \& van Goor, H. (2004). Tissue Distribution of ACE2 Protein, the Functional Receptor forSARS Coronavirus. A FirstStep in Understanding SARS Pathogenesis. Journal of
Pathology, 203(2), 631-637. doi:10.1002/path.1570

Higuchi, R., Fockler, C., Dollinger, G., \& Watson, R. (1993). Kinetic PCR Analysis: Real-Time Monitoring of DNA Amplification Reactions. Biotechnology, 11(9), 1026-1030. doi:10.1038/nbt0993-1026

Hindson, J. (2020). COVID-19: faecal-oral transmission? Nature Reviews: Gastroenterology and Hepatology, 17(5), 259. doi:10.1038/s41575-020-0295-7

Jagodzinski, L.L., Manak, M.M., Hack, H.R., Liu, Y., \& Peel, S.A. (2020). Performance evaluation of a laboratory developed PCR test for quantitation of HIV-2 viral RNA. PLoS One, 15(2), e0229424. doi:10.1371/journal.pone.0229424

Joshi, M., \& Deshpande, J.D. (2011). Polymerase Chain Reaction: Methods, Principles and Application. International Journal of Biomedical Research, 2(1), 81-97. doi:10.7439/ijbr.v2i1.83

Kalifarhood, G., Aghaali, M., Saadati, H.M., Taherpour, N., Rahimi, S., Izadi, N., \& Nazari, S.S.H. (2020). Epidemiological and Clinical Aspects of COVID-19; a Narrative Review. Archives of Academic Emergency Medicine, 8(1), e41.

van Kasteren, P.B., van der Veer, B., van den Brink, S., Wijsman, L., de Jonge, J., van den Brandt, A., Molenkamp, R., Reusken, C.B.E.M., \& Meijer, A. (2020). Comparison of Seven Commercial RT-PCR Diagnostic Kits for COVID-19. Journal of Clinical Virology, 128, 104412. doi:10.1016/j.jcv.2020.104412

King, A.M.Q., Adams, M.J., Carstens, E.B., \& Lefkowitz, E.J. (2011). Virus Taxonomy Ninth Report of the International Committee on Taxonomy of Viruses. Amsterdam, Netherlands: Elsevier B.V.

Kucirka, L.M., Lauer, S.A., Laeyendecker, O., Boon, D., \& Lessler, J. (2020). Variation in False-Negative Rate of Reverse Transcriptase Polymerase Chain Reaction-Based SARS-CoV-2 Tests by Time Since Exposure. Annals of Internal Medicine, M20-1495. doi:10.7326/M20-1495

Lo, I.L., Lio, C.F., Cheong, H.H., Lei, C.I., Cheong, T.H., Zhong, X., Tian, Y., \& Sin, N.N. (2020). Evaluation of SARS-CoV-2 RNA Shedding in Clinical Specimens and Clinical Characteristics of 10 Patients With COVID-19 in Macau. 
International Journal of Biological Sciences, 16(10), 1698-1707. doi:10.7150/ijbs.45357

Long, C., Xu, H., Shen, Q., Zhang, X., Fan, B., Wang, C., Zeng, B., Li, Z., Li, X., \& Li, H. 2020. Diagnosis of the coronavirus disease (COVID-19): rRTPCR or CT? European Journal of Radiology, 126, 108961. doi:10.1016/j.ejrad.2020.108961

Ministry of Health of the Republic of Indonesia. (2020a). Tak Ada Kasus nCoV Positif di Indonesia, Begini Alur Pemeriksaan Lab Balitbangkes. https://www.kemkes.go.id/article/view/20 021200001/tak-ada-kasus-ncov-positif-diindonesia-begini-alur-pemeriksaan-labbalitbangkes.html

Ministry of Health of the Republic of Indonesia. (2020b). Pedoman Kesiapsiagaan Menghadapi Infeksi Novel Corona Virus (COVID-19) Revisi ke - 4. Jakarta, Indonesia: Directorate General of Disease Prevention and Control, Ministry of Health of the Republic of Indonesia.

Mullis, K.B. (1987). Process for amplifying nucleic acid sequences. United States Patent No. 4683202.

Pan, Y., Zhang, D., Yang, P., Poon, L.L.M., \& Wang, Q. (2020). Viral Load of SARS-CoV-2 in Clinical Samples. The Lancet Infectious Diseases, 20(4), 411-412. doi:10.1016/S1473-3099(20)30113-4

Schaad, N.W., \& Frederick, R.D. (2002). Real-time PCR and its application for rapid plant disease diagnostics. Canadian Journal of Plant Pathology, 24(3), 250-258. doi:10.1080/07060660209507006

Tahamtan, A. \& Ardebili, A. (2020). Real-time RT-PCR in COVID-19 Detection: Issues Affecting the Results. Expert Review of Molecular Diagnostics, 20(5), $453-454$. doi:10.1080/14737159.2020.1757437

Thai Public Broadcasting Service World. (2020). Machine error blamed for 40 false positive tests for COVID-19 in Yala. https://www.thaipbsworld.com/machineerror-blamed-for-40-false-positive-tests-forcovid-19-in-yala/

Wan, Y., Shang, J., Graham, R., Baric, R.S., \& Li, F. (2020). Receptor Recognition by the Novel Coronavirus from Wuhan: an Analysis Based on Decade-Long Structural Studies of SARS
Coronavirus. Journal of Virology, 94(7), 1-9. doi:10.1128/JVI.00127-20

Wang, W., Xu, Y., Gao, R., Lu, R., Han, K., Wu, G., \& Tan, W. (2020). Detection of SARS-CoV-2 in Different Types of Clinical Specimens. JAMA, 323(18), 1843-1844. doi:10.1001/jama.2020.3786

Wölfel, R., Corman, V.M., Guggemos, W., Seilmaier, M., Zange, S., Müller, M.A., Niemeyer, D., Jones, T.C., Vollmar, P., Rothe, C., Hoelscher, M., Bleicker, T., Brünink, S., Schneider, J., Ehmann, R., Zwirglmaier, K., Drosten, C., \& Wendtner, C. (2020). Virological Assessment of Hospitalized Patients With COVID-2019. Nature, 581(7809), 465-469. doi:10.1038/s41586020-2196-x

World Health Organization. (2006). Collecting, Preserving and Shipping Specimens for The Diagnosis of Avian Influenza A(H5N1) virus infection. Guide for Field Operations. https://www.who.int/ihr/publications/An nex8.pdf?ua $=1$

World Health Organization. (2020a). Guidance for Laboratories Shipping Specimens to WHO Reference Laboratories That Provide Confirmatory Testing For COVID-19 Virus. https://apps.who.int/iris/bitstream/handle /10665/331639/WHO-2019-nCoVlaboratory_shipment-2020.3-eng.pdf

World Health Organization. (2020b). Laboratory testing for coronavirus disease 2019 (COVID-19) in suspected human cases. https://www.who.int/publicationsdetail/laboratory-testing-for-2019-novelcoronavirus-in-suspected-human-cases20200117

World Health Organization. (2020c). Interim Guidance: Clinical Management of Covid-19. https://www.who.int/publicationsdetail/clinical-management-of-covid-19

Worldometer. (2020). COVID-19 Coronavirus Pandemic. https://www.worldometers.info/coronaviru s/

Zhang, L., Huang, Y., He, T., Cao, Y., \& Ho, D. D. 1996. HIV-1 Subtype and Second-Receptor Use. Nature, 383(6603), 768. doi:10.1038/383768a0 
Zou, L., Ruan, F., Huang, M., Liang, L., Huang, H., Hong, Z., Yu, J., Kang, M., Song, Y., Xia, J., Guo, Q., Song, T., He, J., Yen, H.L., Peiris, M., \& Wu, J. (2020). SARS-CoV-2 Viral Load in Upper Respiratory Specimens of Infected Patients. The New England Journal of Medicine, 382(12): 1175-1177. doi:10.1056/NEJMc2001737 